\title{
Vibroacoustic methodes of assessing valve clearance in combustion engines. An analysis of signals in the area of amplitude - point discriminants
}

\author{
This article presents results of research referring to applying selected point parameters of vibration signal to assess \\ valve clearance of combustion engines. The authors indicate necessity to apply a complex process to prepare signal of \\ vibration accelerations before making calculations of point parameters characterizing vibroacoustic signal in order to \\ decrease the risk of inaccurate analysis.
}

Key words: internal combustion engine, vibroacoustic diagnostics

\section{Wibroakustyczne metody szacowania luzu zaworów silników spalinowych. Analiza sygnałów w dziedzinie amplitud - dyskryminanty punktowe}

\begin{abstract}
$W$ artykule przedstawiono wyniki badań dotyczace zastosowania wybranych miar punktowych sygnatu drganiowego do oceny luzu zaworów silnika spalinowego. Wskazano konieczność zastosowania złożonego procesu przygotowania sygnału przyspieszeń drgań, przed wykonaniem obliczeń miar punktowych charakteryzujących sygnat wibroakustyczny w celu zmniejszenia ryzyka błędnej diagnozy.

Słowa kluczowe: silnik spalinowy, diagnostyka wibroakustyczna
\end{abstract}

\section{Introduction}

Cam unit, which operates exchange of load, is one of basic systems of internal combustion engine. Providing optimal regulating parameters in the whole operation time, is a condition of appropriate operation of cam unit. In internal combustion engines valve clearance (between the valve rod and lever or cam) is one of the main parameters regulating cam unit.

Incorrectly aligned valve clearance in a reason of decrease in efficiency of combustion engine operation, increase of toxic compounds emission into the atmosphere and may, as well, lead to damage of parts of cam unit of combustion engine e.g. partial burning of valve face and seat face of valve [4].

Applying automatic compensation of valve clearance enables elimination of necessity to align periodically valve clearance in combustion engines. However, putting additional masses into cam unit causes increase of inertial forces and beside this, an additional device increases possibility of damage because it is applied in series into the kinematic chain of cam unit. Out of control increase of valve clearance is a result of damage to automatic compensator of valve clearance.

The purpose of this research is to evaluate usability of selected point parameters of vibration signal generated by internal combustion engine's head to assess valve clearance and to present preparing process of converting signal of vibration accelerations for optimal usage of incorporated information about the condition of valve clearance.

\section{Point parameters in vibration signals analysis}

Point parameters are a few of many signal characteristics of displacement, speed or vibration accelerations [1, 2]. They allow characterizing vibration signal with only one number. Thanks to such description of vibration parameters

\section{Wprowadzenie}

Jednym z podstawowych zespołów tłokowego silnika spalinowego jest układ rozrządu, który steruje wymianą ładunku. Warunkiem prawidłowego działania układu rozrządu jest zapewnienie optymalnych wartości parametrów regulacyjnych w całym okresie jego eksploatacji. Jednym z głównych parametrów regulacyjnych rozrządu silnika spalinowego jest luz zaworowy (między trzonkiem zaworu a dźwignią lub krzywką).

Nieprawidłowo wyregulowany luz zaworów jest przyczyną pogorszenia efektywności pracy silnika spalinowego, zwiększenia emisji związków toksycznych do atmosfery, a także może doprowadzić do uszkodzenia elementów układu rozrządu silnika spalinowego, np. nadpalenie przylgni zaworów lub gniazd zaworowych [4].

Zastosowanie automatycznej kompensacji luzów zaworowych umożliwia wyeliminowanie konieczności okresowej regulacji luzu zaworów w silnikach spalinowych. Jednak wprowadzenie do układu rozrządu dodatkowych mas powoduje zwiększenie sił bezwładności, poza tym dodatkowe urządzenie zwiększa prawdopodobieństwo uszkodzeń, ponieważ jest włączone szeregowo w łańcuchu kinematycznym układu rozrządu. Konsekwencją uszkodzenia automatycznego kompensatora luzu zaworowego jest niekontrolowany wzrost luzu zaworów.

Celem badań jest ocena przydatności wybranych miar punktowych sygnału drgań generowanego przez głowicę silnika spalinowego do oszacowania luzów zaworów oraz przedstawienie procesu wstępnego przetworzenia sygnału przyspieszeń drgań dla optymalnego wykorzystania zawartej w nim informacji o stanie luzu zaworowego. 
it is easy to determine changes in vibroacoustic signal, which are a result of changes in object's technical condition. Point parameters applied in vibroacoustic diagnostics can be divided according to [1] into dimensional and non-dimensional parameters. Dimensional point parameters include:

a) average amplitude

$$
\mathrm{s}_{\text {AVERAGE }}=\frac{1}{\mathrm{~T}} \int_{0}^{\mathrm{T}}|\mathrm{s}(\mathrm{t})| \mathrm{dt}
$$

it equally regards each value of instantaneous amplitude of vibration signal,

b) RMS amplitude:

$$
\mathrm{S}_{\mathrm{RMS}}=\sqrt{\frac{1}{\mathrm{~T}} \int_{0}^{\mathrm{T}}[\mathrm{s}(\mathrm{t})]^{2} \mathrm{dt}}
$$

it regards to a greater extent great values of instantaneous amplitude, it is the most often applied point parameter because of its proportionality to process power,

c) square amplitude:

$$
\mathrm{s}_{\text {SQUARE }}=\left[\frac{1}{\mathrm{~T}} \int_{0}^{\mathrm{T}}|\mathrm{s}(\mathrm{t})|^{\frac{1}{2}} \mathrm{dt}\right]^{2}
$$

it regards to a greater extent little values of instantaneous amplitude of vibration signal,

d) peak amplitude:

$$
\mathrm{S}_{\text {PEAK }}=\left[\frac{1}{\mathrm{~T}} \int_{0}^{\mathrm{T}}|\mathrm{s}(\mathrm{t})| \mathrm{dt}\right]^{\frac{1}{\infty}}
$$

it is used to evaluate impact processes e.g. clearance, impacts, etc.,

e)peak-to-peak amplitude :

$$
\mathrm{s}_{\text {PEAKtoPEAK }}=\max |\mathrm{s}(\mathrm{t})>0|+\max |\mathrm{s}(\mathrm{t})<0|
$$

it is used similarly to peak value to evaluate impact processes e.g. clearance, impacts, etc.

Non-dimensional discriminants are a quotient of appropriate dimensional point parameters, they include the following values:

f) shape coefficient:

$$
\mathrm{K}=\frac{\mathrm{s}_{\mathrm{RMS}}}{\mathrm{s}_{\text {AVERAGE }}}
$$

g) peak coefficient:

$$
\mathrm{C}=\frac{\mathrm{S}_{\mathrm{PEAK}}}{\mathrm{S}_{\mathrm{RMS}}}
$$

h) impulse coefficient:

$$
\mathrm{I}=\frac{\mathrm{S}_{\text {PEAK }}}{\mathrm{S}_{\text {AVERAGE }}}
$$

i) clearance coefficient:

$$
\mathrm{L}=\frac{\mathrm{S}_{\text {PEAK }}}{\mathrm{S}_{\text {SQUARE }}}
$$

\section{Miary punktowe w analizie sygnalów drganiowych}

Miary punktowe są jednymi z wielu charakterystyk sygnałów przemieszczeń, prędkości lub przyspieszeń drgań $[1,2]$. Pozwalają scharakteryzować sygnał drganiowy za pomocą jednej liczby. Dzięki takiemu opisowi parametrów drgań łatwo jest określić zmiany w sygnale wibroakustycznym, będące wynikiem zmian stanu technicznego obiektu. Miary punktowe stosowane w diagnostyce wibroakustycznej (DWA) można podzielić zgodnie z [1] na wymiarowe i bezwymiarowe. Do miar punktowych wymiarowych należą:

a) amplituda średnia (1) - w jednakowym stopniu uwzględnia każdą wartość amplitudy chwilowej sygnału drgań,

b) amplituda skuteczna (2) - w większym stopniu uwzględnia duże wartości amplitudy chwilowej, jest najczęściej stosowaną miarą punktową ze względu na proporcjonalność do mocy procesu,

c) amplituda pierwiastkowa (3) - w większym stopniu uwzględnia małe wartości amplitudy chwilowej sygnału drgań,

d) amplituda szczytowa (4) - jest używana do oceny procesów impulsowych, np. luzy, uderzenia itp.,

e) amplituda międzyszczytowa (5) - jest używana podobnie jak wartość szczytowa do oceny procesów impulsowych, np. luzy, uderzenia itp.

Dyskryminanty bezwymiarowe są ilorazami odpowiednich miar punktowych wymiarowych, zalicza się do nich następujące wielkości:

f) współczynnik kształtu (6),

g) współczynnik szczytu (7),

h) współczynnik impulsowości (8),

i) współczynnik luzu (9),

j) kurtoza (10).

W zależnościach od (1) do (10) zastosowano oznaczenia: $\mathrm{s}(\mathrm{t})$ - chwilowa wartość amplitudy przemieszczeń, prędkości lub przyspieszeń drgań, $\mathrm{t}$ - czas, $\mathrm{T}$ - czas uśredniania.

W pracach $[1,6]$ udowodniono, że z punktu widzenia przydatności diagnostycznej miary punktowe bezwymiarowe można uszeregować $\mathrm{w}$ porządku rosnącej wartości $\mathrm{K}, \mathrm{C}, \beta, \mathrm{I}, \mathrm{L}$.

\section{Metodyka i obiekt badań}

Badania przeprowadzono zgodnie z własną metodyką badań. Obiektem badań był silnik spalinowy o ZS typu SB 3.1. Do badań przyjęto następujące parametry pracy silnika: prędkość obrotowa $700 \mathrm{obr} / \mathrm{min}$, moment obrotowy bez obciążenia (ok. $3 \mathrm{~N} \cdot \mathrm{m}$ opory własne hamulca), temperatura cieczy chłodzącej $75^{\circ} \mathrm{C}$.

Badania przeprowadzono zgodnie zasadami eksperymentu czynnego. Zmieniano wartość luzu pomiędzy trzonkiem zaworów a dźwignią zaworową i równocześnie obserwowano zmiany zachodzące $\mathrm{w}$ wartościach miar punktowych sygnałów prędkości i przyspieszeń drgań. Luzy zaworowe zmieniano $\mathrm{w}$ zakresie $0,3-1 \mathrm{~mm}$ z krokiem $0,1 \mathrm{~mm}$.

Akwizycji poddano sygnały przyspieszeń oraz prędkości drgań w trzech wzajemnie prostopadłych kierunkach. Ponadto mierzono sygnał ciśnienia panującego w cylindrze oraz rejestrowano znacznik kąta obrotu wału korbowego. Do rejestracji 
j) kurtosis:

$$
\beta=\frac{\frac{1}{\mathrm{~T}} \int_{0}^{\mathrm{T}}[\mathrm{s}(\mathrm{t})]^{4} \mathrm{dt}}{\left[\frac{1}{\mathrm{~T}} \int_{0}^{\mathrm{T}}[\mathrm{s}(\mathrm{t})]^{2} \mathrm{dt}\right]^{2}}
$$

Depending on (1) to (10) the following marks are used: $s(t)$ - instantaneous value of displacement, speed or vibration accelerations, $\mathrm{t}$ - time, $\mathrm{T}$ - average time.

In papers $[1,5]$ it was proved that from the perspective of diagnostics usability non-dimensional point parameters can be ranged in order of increasing value: $\mathrm{K}, \mathrm{C}, \beta, \mathrm{I}, \mathrm{L}$.

\section{Methodology and research object}

The research was carried out in accordance with authors' own research methodology. A combustion engine CI type SB 3.1 was the object of the research. In the research the following parameters of engine operations were taken: motor speed of $700 \mathrm{rpm}$, motor torque without load (approx. $3 \mathrm{~N} \cdot \mathrm{m}$ brake's own resistances) cooling liquid temperature of $75^{\circ} \mathrm{C}$.

The research was carried out in accordance with principles of active experiment. A value of clearance between valve stem and valve lever was changed, and at the same time, changes of values of point parameters of speed signals and vibration accelerations were observed. Valve clearance was changed in the range of $0.3 \div 1 \mathrm{~mm}$ with step $0.1 \mathrm{~mm}$.

Acceleration signals and vibration velocity of vibration signals in three reciprocally orthogonal directions were acquired. Additionally, pressure signal in cylinder was measured and angle marker of crankshaft rotation was registered. To register the time flows of mentioned values a system PULSE B\&K 3560 C with triaxial piezoelectric accelerometer, piezoelectric pressure convector, angle marker of crankshaft, was used.

Papers $[2,4]$ present detailed assumptions referring to elaborating research methodology of influence of clearance valve of combustion engine on selected characteristics of vibration signals.

\section{Analysis of selected research results}

In the preparing research it was found that parameters of vibration signals registered in the parallel direction to axe of the crankshaft enable unequivocal determination of valve clearance (for engine type SB 3.1).

Before defining point parameters, the signals were subject of time selection. This means that in the calculations only the time flow intervals of vibration accelerations, which temporarily (angularly) were connected with a moment of valve closing [2] were taken into account. The operation of time selection was necessary because without applying it, calculated point parameters of signals of vibration accelerations had been characterized by insufficient, for diagnostics purposes, dynamics of changes in the function of valve clearance.

On the basis of signal prepared in the described way the authors calculated point parameters which are the most susceptible to impact effects in mechanical systems. These are peakto-peak value and kurtosis of vibration acceleration [1]. przebiegów czasowych wymienionych wielkości użyto systemu PULSE B\&K 3560 C wraz z trójosiowym piezoelektrycznym przetwornikiem drgań, piezoelektrycznym przetwornikiem ciśnienia, znacznikiem kąta obrotu wału korbowego.

Szczegółowe założenia dotyczące opracowania metodyki badań wpływu luzu zaworów silnika spalinowego na wybrane charakterystyki sygnałów drgań przedstawiono w pracach $[4,5]$.

\section{Analiza wybranych wyników badań}

W trakcie badań wstępnych stwierdzono, że jednoznaczne określenie wartości luzu zaworowego umożliwiają parametry sygnałów drgań zarejestrowanych w kierunku równoległym do osi wału korbowego (dla silnika SB 3.1).

Przed wyznaczeniem miar punktowych sygnały poddano selekcji czasowej. Oznacza to, że w obliczeniach uwzględniono tylko te odcinki przebiegów czasowych przyspieszeń drgań, które czasowo (kątowo) były związane z momentem zamykania zaworów [2]. Operacja selekcji czasowej była konieczna, ponieważ bez jej zastosowania obliczone miary punktowe sygnałów przyspieszeń drgań charakteryzowały się niewystarczającą, do celów diagnostycznych, dynamiką zmian w funkcji luzu zaworowego. Na podstawie tak przygotowanego sygnału obliczono miary punktowe, które są najbardziej wrażliwe na zjawiska udarowe w układach mechanicznych - wartość międzyszczytową i kurtozę przyspieszeń drgań [1].

Na rysunku 1 przedstawiono zależność szczytowej wartości przyspieszeń drgań $\mathrm{w}$ funkcji luzu zaworów silnika spalinowego, którą aproksymowano (metodą najmniejszych kwadratów) funkcją wykładniczą. W wyniku aproksymacji otrzymano równanie krzywej (11). Podczas badań wyznaczono dynamikę zmian parametru sygnału drgań, która wyniosła $6,9 \mathrm{~dB}$.

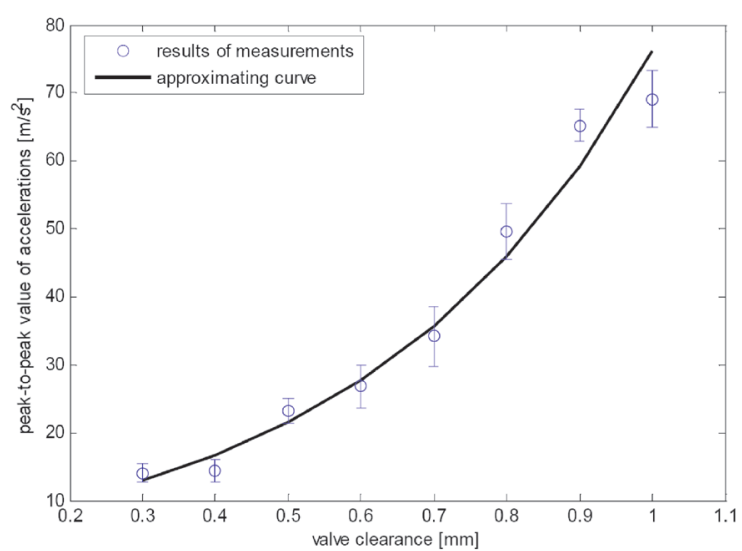

Fig. 1. Dependence of peak-to-peak value on vibration acceleration and valve clearance of combustion engine type SB 3.1

Rys. 1. Zależność wartości międzyszczytowej przyspieszeń drgań od luzu zaworów silnika spalinowego $S B 3.1$

Podstawowym celem badań diagnostycznych jest określenie luzu zaworów na podstawie znanych wartości parametrów przyspieszeń drgań; w tym celu przeprowadzono obliczenia w oparciu o krzywą aproksymującą. W równaniu 
Figure 1 presents dependence of peak value of vibration acceleration in the function of valve clearance of combustion engine, the function was approximated (with the method of least squares) with the exponential function. The approximation resulted in curve equation (11). During the research a dynamics of changes of vibration signal parameter was determined. The dynamics amounted to $6.9 \mathrm{~dB}$

$$
\mathrm{a}_{\mathrm{x} \text { PEAK TO PEAK }}=6.0892 \cdot \mathrm{e}^{2.5277 \cdot \mathrm{L}_{\mathrm{z}}}
$$

The main purpose of diagnostics tests is to define valve clearance on the basis of given values of parameters of vibration accelerations. For this reason, calculations on the basis of approximating curve were carried out. In the equation peak-to-peak value of vibration accelerations is taken as the explaining variable and valve clearance as the explained variable. As a result of calculating approximation coefficients a curve described with equation (12) was obtained. The curve is described in Fig. 2.

$$
\mathrm{L}_{\mathrm{z}}=0.3868 \cdot \ln \left(\mathrm{a}_{\mathrm{x} \text { PЕАК TO РЕАК }}\right)-0.6844
$$

where: $a_{x \text { PEAKTOPEAK }}$ means peak-to-peak value of vibration acceleration $\left[\mathrm{m} / \mathrm{s}^{2}\right], \mathrm{L}_{\mathrm{z}}$ means valve clearance $[\mathrm{mm}]$.

The value of correlation coefficient between measurements results and values obtained during calculations using dependence (11) amounted to 0.98 , which means a good representation of real measurements in mathematical model describing changes of valve clearance depending on peakto-peak value of vibration accelerations.

Figure 3 presents relation between kurtosis of vibration accelerations in function of valve clearance. The dynamics of changes of kurtosis in function of valve clearance amounted to $9.5 \mathrm{~dB}$.

On the basis of defined parameters approximation was carried out with a method of least squares. Approximated curve is presented with equation (13):

$$
\beta_{\text {ax }}=0.8353 \cdot \mathrm{e}^{3.6376 \cdot \mathrm{L}_{\mathrm{z}}}
$$

To assess valve clearance on the basis of the value of kurtosis of vibration accelerations signal a mathematical model was defined. This model was defined on the basis of the method of least squares. A curve described with equation (14) is a result of the approximation. This curve is presented in Fig. 4.

$$
\mathrm{L}_{\mathrm{z}}=0.2559 \cdot \ln \left(\beta_{\mathrm{ax}}\right)+0.0909
$$

where: $\beta_{\mathrm{ax}}$ means value of kurtosis of vibration accelerations, $\mathrm{L}_{\mathrm{z}}$ means valve clearance $[\mathrm{mm}]$.

On the basis of measurements results and values obtained during calculations using dependence (13) a correlation coefficient was defined. This coefficient amounted to 0.96 . This means a good representation of real measurements in mathematical model describing changes of valve clearance depending on kurtosis of vibration acceleration.

\section{Conclusion}

On the basis of analysis of research results referring to possibility of applying point parameters to assess valve za zmienną objaśniającą przyjęto wartość międzyszczytową przyspieszeń drgań, a za zmienną objaśnianą - luz zaworów. W wyniku obliczeń współczynników aproksymacji otrzymano krzywą przedstawioną na rys. 2, opisaną równaniem (12), gdzie: $a_{x \text { PEAK TO PEAK }}$ - wartość międzyszczytowa przyspieszeń drgań $\left[\mathrm{m} / \mathrm{s}^{2}\right], \mathrm{L}_{\mathrm{z}}-$ luz zaworów [mm].

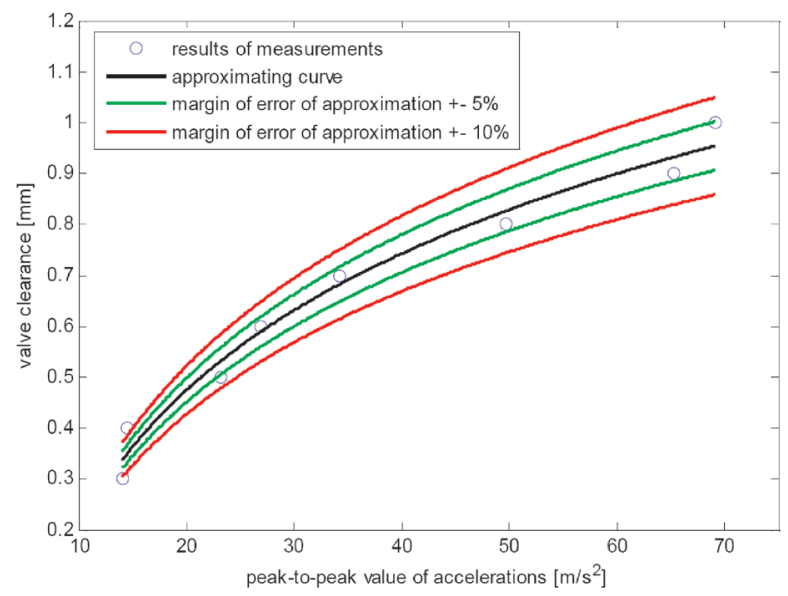

Fig. 2. Dependence of valve clearance of combustion engine type SB 3.1 on peak-to-peak value

Rys. 2. Zależność luzu zaworów silnika spalinowego SB 3.1 od wartości międzyszczytowej

Wartość współczynnika korelacji pomiędzy wynikami pomiarów a wartościami uzyskanymi w trakcie obliczeń, wykorzystując zależność (11), wyniosła 0,98 , co oznacza dobre odwzorowanie rzeczywistych pomiarów w modelu matematycznym opisującym zmiany luzu zaworów w zależności od wartości międzyszczytowej przyspieszeń drgań.

Na rysunku 3 przedstawiono zależność kurtozy przyspieszeń drgań w funkcji luzu zaworów. Dynamika zmian kurtozy w funkcji luzu zaworów wyniosła 9,5 dB.

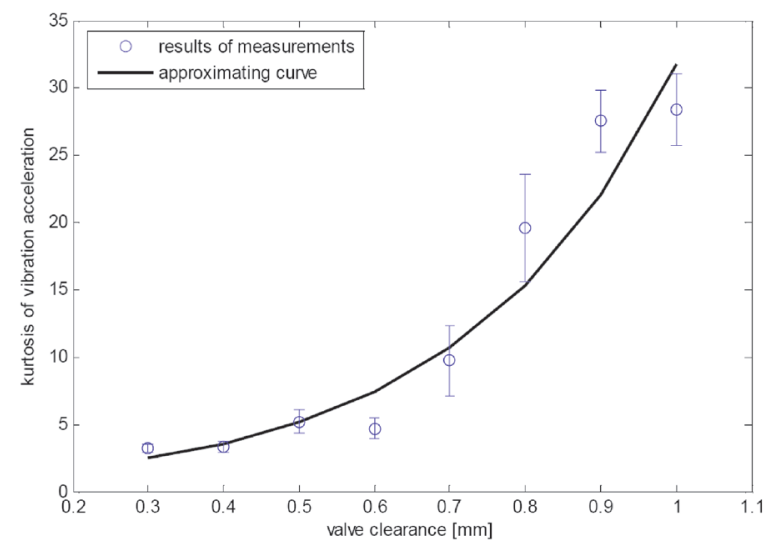

Fig. 3. Dependence of kurtosis of vibration accelerations on valve clearance of combustion engine type SB 3.1

Rys. 3. Zależność kurtozy przyspieszeń drgań od luzu zaworów silnika spalinowego $S B 3.1$

Na podstawie wyznaczonych punktów przeprowadzono aproksymację metodą najmniejszych kwadratów. Aproksymowaną krzywą przedstawiono równaniem (13). 
clearance it was found out that selected discriminants enable to assess unequivocally valve clearance. High susceptibility into changes of valve clearance and uniqueness were observed for signal registered in parallel direction to axe of crankshaft (in engine type SB 3.1).

Moreover, it was determined that making time series subject of time selection is a condition to obtain satisfactory accuracy of assessing valve clearance on the basis of peak-to-peak value and kurtosis of accelerations calculated from vibration signal.

During verification of diagnostics models based on point parameters of signal of vibration accelerations of the head it was found out, that differences in assessing valve clearance for particular start-ups did not exceed 3\% for diagnostics models constructed on the basis of peak-to-peak values of vibration accelerations and 5\% for models using kurtosis of vibration accelerations.

Further research referring to possibility to assess valve clearance will comprise tests aiming at applying frequency analysis in description of effects taking place in cam unit of combustion engine and assessment of its technical condition.

This scientific work was financed from science resources for years 2008-2011 as research project No. N N502463034.

\section{Paper reviewed/Artykut recenzowany}

\section{Bibliography/Literatura}

[1] Cempel Cz.: Podstawy wibroakustycznej diagnostyki maszyn, WNT, Warszawa 1982.

[2] Czechyra B., Szymański G., Tomaszewski F.: Assessment of camvalves clearance in internal combustion engine based on parameters of vibration - methodological assumption. Combustion Engines nr 1/2004(118).

[3] Szymański G.: Ocena stanu regulacji zaworów silnika spalinowego za pomocą sygnału drganiowego. Praca magisterska, Politechnika Poznańska, Poznań 2000.

[4] Szymański G.: Analiza możliwości zastosowania wybranych charakterystyk sygnału drganiowego do diagnostyki silnika spalinowego. Rozprawa doktorska, Politechnika Poznańska, Poznań 2005.

[5] Tomaszewski F.: Zastosowanie procesów wibroakustycznych do oceny stanu technicznego silnika spalinowego lokomotywy. Praca doktorska, Politechnika Poznańska, Poznań 1987.

Prof. Franciszek Tomaszewski, DSc., DEng. - Professor in the Faculty of Working Machines and Transportation at Poznan University of Technology.

Dr hab. inż. Franciszek Tomaszewski - profesor na Wydziale Maszyn Roboczych i Transportu Politechniki Poznańskiej.

e-mail: Franciszek.Tomaszewski@put.poznan.pl

Mr. Grzegorz M. Szymański, DEng. - doctor in the Faculty of Working Machines and Transportation at Poznan University of Technology.

Dr inż. Grzegorz M. Szymański - adiunkt na Wydziale Maszyn Roboczych i Transportu Politechniki Poznánskiej.

e-mail: grzegorz.m.szymanski@put.poznan.pl
W celu oszacowania luzu zaworów na podstawie wartości kurtozy sygnału przyspieszeń drgań wyznaczono model matematyczny, opierając się na metodzie najmniejszych kwadratów. Wynikiem aproksymacji jest krzywa opisana równaniem (14) przedstawiona na rys. 4 , gdzie: $\beta_{\mathrm{ax}}$ - wartość kurtozy przyspieszeń drgań, $\mathrm{L}_{\mathrm{z}}$ - luz zaworów [mm].

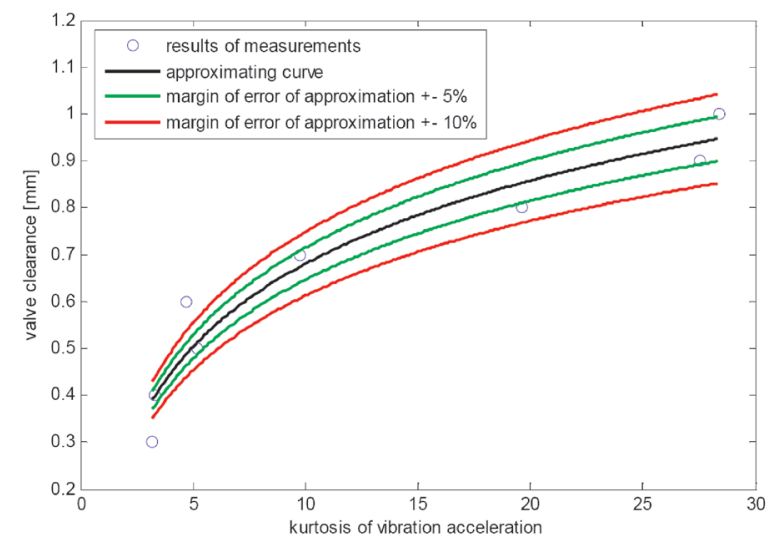

Fig. 4. Dependence of valve clearance of combustion engine type SB 3.1 on value of kurtosis of vibration accelerations

Rys. 4. Zależność luzu zaworów silnika spalinowego SB 3.1 od wartości kurtozy przyspieszeń drgań

Na podstawie wyników pomiarów i wartości uzyskanych w trakcie obliczeń z wykorzystaniem zależności (13) wyznaczono współczynnik korelacji, który wyniósł 0,96 . Oznacza to dobre odwzorowanie rzeczywistych pomiarów w modelu matematycznym opisującym zmiany luzu zaworów w zależności od kurtozy przyspieszeń drgań.

\section{Podsumowanie}

Na podstawie analizy wyników badań dotyczących możliwości zastosowania miar punktowych do oceny luzu zaworów stwierdzono, że wybrane dyskryminanty pozwalają oszacować jednoznacznie luz zaworów. Dużą wrażliwość na zmianę luzu zaworowego oraz jednoznaczność zaobserwowano dla sygnału zarejestrowanego w kierunku równoległym do osi wału korbowego (dla silnika SB 3.1).

Ustalono ponadto, że warunkiem uzyskania zadowalającej dokładności oszacowania luzu zaworów na podstawie wartości międzyszczytowej i kurtozy przyspieszeń obliczonych z sygnału drganiowego jest poddanie szeregów czasowych preprocesingowi polegającemu na selekcji czasowej.

Podczas weryfikacji modeli diagnostycznych opartych na miarach punktowych sygnałów przyspieszeń drgań głowicy stwierdzono, że różnice oszacowania luzów zaworów dla poszczególnych uruchomień nie przekraczały 3\% dla modeli diagnostycznych zbudowanych na podstawie wartości międzyszczytowych przyspieszeń drgań oraz $5 \%$ dla modeli wykorzystujących kurtozę przyspieszeń drgań.

Dalsze prace dotyczące możliwości oceny luzu zaworów będą obejmowały badania zmierzające do zastosowania analizy częstotliwościowej w opisie zjawisk zachodzących w układzie rozrządu silnika spalinowego oraz do jego oceny. 